\title{
MEETINGS OF INTEREST
}

\section{ICOS XIX}

The International Congress of Onomastic Sciences is scheduled for 4-11 August, 1996, at the University of Aberdeen, Scotland. Arrangements are being handled by Professor W. F. H. Nicolaisen. The first circular will be sent in September, 1994. For information before then, contact Professor Nicolaisen directly at the Department of English, King's College, University of Aberdeen, Scotland AB9 2UB. Telephone: 011-44-224-272625. Fax: 011-44224-272624.

\section{CALL FOR PAPERS}

The American Name Society is seeking papers to be presented at the ANS session of M/MLA, the Midwest Modern Language Association, which will be held in Chicago, II on 11-13 November 1994. Papers on any areas of onomastics will be considered, but those with a Chicago/llinois/Midwest emphasis will be especially appreciated. Abstracts for 20-minute papers should be sent by 15 April 1994 to the session coordinator

\author{
Professor Thomas E. Murray \\ Department of English \\ Kansas State University \\ Manhattan, KS 66506-0701 \\ FAX: 913-532-7004 \\ e-mail: TEM@KSUVM.BITNET
}

